The dominant theme which appears to emerge from the answers to questions 6 and 8 seems to be a desire on the part of European physicists to broaden their knowledge and experience. This is further illustrated by the worthwhile topics mentioned by isolated individuals, such as the management of research and development, venture capital management in relation to physics, the international recognition and standardisation of diplomas and the comparison of university-industry relations between different European countries. Gratifyingly, if surprising, it was a few physicists from larger European countries who expressed the sentiment that EPS could supply the broader framework which individual European countries could not provide.

\section{Conclusion}

Both in regard to the more general written remarks and the voting on the services to Associate Members, it is clearly necessary to study more fully such questions as the extent to which the opinions expressed are representative of EPS as a whole; and moreover are directly applicable to the interests of Associate Members. The balance between the resources, including finance, needed to carry out the suggestions will clearly have to be weighed against the benefits likely to follow. Such further consideration will constitute a vital part on the immediate future activities of the Advisory Committee on Applied Physics and Physics in Industry. Moreover, before the Advisory Committee submits its recommendations to the Executive Committee, it will await the outcome of the business meeting with Associate Members at Wiesbaden to which reference was made in the introduction to this article.

\section{Optical spectroscopy of solids}

\section{Edited by B. Rosen}

and J. Depireux.

The Proceedings of the $X$ th European Congress on Molecular Spectroscopy, held in Liège in 1969 , are available under the above title.

Price : BF 500.-.

Société Royale des Sciences de Liège, avenue des Tilleuls 45, B-4000 Liège, Belgium.

\title{
EPS General Conference
}

\author{
Wiesbaden, 3-6 October 1972
}

\section{Theme: Trends in Physics}

On 3-6 October 1972 in Wiesbaden, FDR, EPS will hold its Second General Conference and an associated Physics Exhibition. The aims of the Conference and Exhibition were described in the last issue of Europhysics News (3 (1) January/February 1972), and this present article is a progress report.

The provisional programme is set out in full on the opposite page and contains details of the speakers at the plenary sessions in the mornings and evenings. Preliminary information on the sessions organized by EPS Divisions is given at the end of this introduction.

Invitations have been sent out to companies to inform them about the Physics Exhibition and about the Handbook in which they may publish advertisements. Associate Members will be entitled to claim $25 \%$ discount, both on exhibition space and on advertisements. Exhibitors will be able to publish details of their products and services in the Handbook.

In order to encourage the attendance of student physicists, 200 beds have been reserved in the youth hostel in Wiesbaden where bed and breakfast would be available for DM 6.50 per night. Several national societes have also been able to arrange special grants for students wishing to attend.

\section{General Assembly}

Wiesbaden, 4 October 1972

On Wednesday. 4 October 1972, at $15.30 \mathrm{hrs}$, the General Assembly of the European Physical Society will meet at Wiesbaden in ordinary session (following Article 12 of the Constitution), on the occasion of the Second EPS General Conference.

Individual Ordinary Members and Member Societies of EPS (one delegate per Society for the latter category) are invited and are urged to attend. During the meeting, reports will be presented by the President, the Secretary and the Treasurer on the development of EPS and on plans for the future. A discussion period will follow. Details of the Agenda will be announced at a later date.

To attend the Conference or to book space at the Physics Exhibition, please contact

\section{Mr. U. Dihle,}

Physikalisches Institut

der Universität,

Robert Mayer-Strasse 2-4,

D-6000 Frankfurt/Main, FDR.

(Telephone 7797 31).

\section{Divisional sessions}

ASTRONOMY AND ASTROPHYSICS

Gravitational waves D. Sciama

(Oxford, UK)

High energy astrophysics $K$. Pinkau

(Munich, FDR)

Infra-red astrophysics

P. Léna (Meudon, France)

Astrophysical aspects of highly collapsed

bodies F. Pacini (Frascati, Italy)

ASTRONOMY AND ASTROPHYSICS COMPUTATIONAL PHYSICS

\section{Spiral structure of galaxies}

F. Hohl (Hampton, USA)

Computing experiments on stellar systems

P. Bouvier (Geneva, Switzerland)

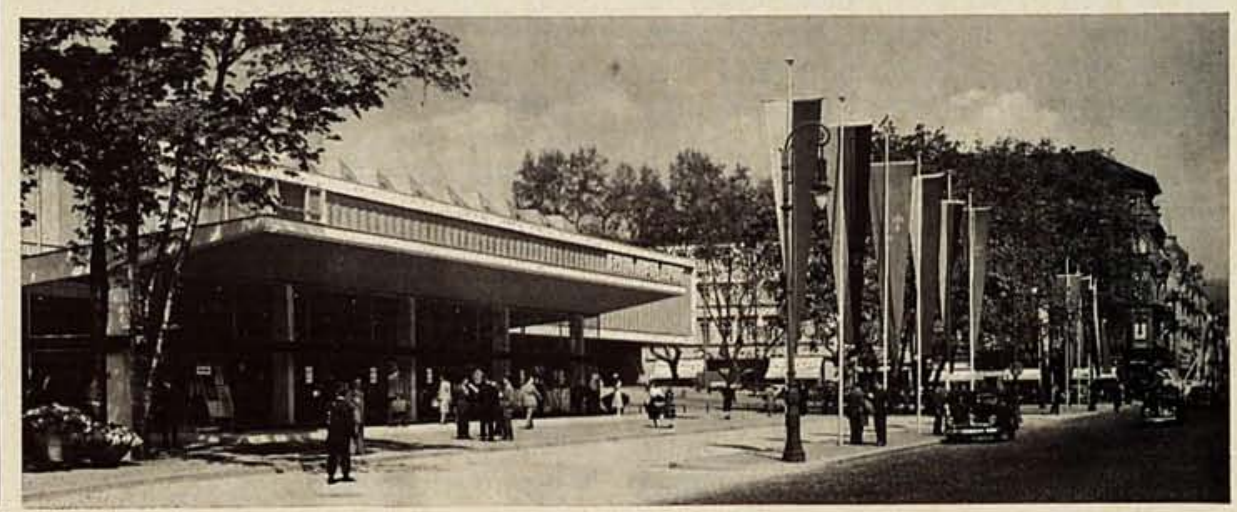


Provisional Programme

\begin{tabular}{|c|c|c|c|c|}
\hline Time & Tuesday, 3 & Wednesday, 4 & Thursday, 5 & Friday, 6 \\
\hline $\begin{array}{c}9.00 \\
\text { to } \\
12.30\end{array}$ & $\begin{array}{l}\text { OPENING SESSION } \\
\text { EPS President } \\
\text { Mayor of Wiesbaden } \\
\text { DPG President } \\
\text { Minister of Education, } \\
\text { FDR } \\
\text { Origin of the universe } \\
\text { W. Kundt } \\
\text { (Hamburg, FDR) } \\
\text { Environmental scientific } \\
\text { research and economic } \\
\text { policy } \\
\text { J. Tinbergen (The Hague) }\end{array}$ & $\begin{array}{l}\text { Recent developments } \\
\text { in high energy physics } \\
\text { L. van Hove } \\
\text { (Geneva, Switzerland) } \\
\text { Non-linear optics and } \\
\text { short light pulses } \\
\text { W. Kaiser } \\
\text { (Munich, FDR) } \\
\text { Quantum interferometers } \\
\text { B. Goodman (London) }\end{array}$ & $\begin{array}{l}\text { Fusion } \\
\text { L.A. Artsimovich } \\
\text { (Moscow) } \\
\text { Physical aspects of } \\
\text { displays } \\
\text { S. van Houten } \\
\text { (Eindhoven, } \\
\text { The Netherlands) } \\
\text { Neutron precession } \\
\text { in polarized targets } \\
\text { A. Abragam (Paris) }\end{array}$ & $\begin{array}{l}\text { Geophysics of the } \\
\text { atmosphere } \\
\text { G. Fiocci } \\
\text { (Frascati, Italy) } \\
\text { Atoms dressed } \\
\text { by photons } \\
\text { C. Cohen-Tanoudji } \\
\text { (Paris) } \\
\text { Exotic atoms } \\
\text { Speaker not confirmed }\end{array}$ \\
\hline $\begin{array}{c}14.30 \\
\text { to } \\
18.00\end{array}$ & $\begin{array}{l}\text { In parallel: } \\
\text { HIGH ENERGY AND } \\
\text { PARTICLE PHYSICS } \\
\text { ATOMIC PHYSICS } \\
\text { QUANTUM } \\
\text { ELECTRONICS } \\
\text { PLASMA PHYSICS } \\
\text { CONDENSED MATTER } \\
\text { - LOW TEMPERATURE } \\
\text { PHYSICS }\end{array}$ & $\begin{array}{l}\text { Chemical lasers and } \\
\text { chemical reactions } \\
\text { induced by lasers } \\
\text { A. Oraevski (Moscow) } \\
\text { GENERAL ASSEMBLY } \\
\text { Meeting with EPS } \\
\text { Associate Members }\end{array}$ & $\begin{array}{l}\text { In parallel: } \\
\text { ATOMIC } \\
\text { SPECTROSCOPY } \\
\text { ASTRONOMY } \\
\text { HIGH ENERGY AND } \\
\text { PARTICLE PHYSICS - } \\
\text { NUCLEAR PHYSICS } \\
\text { PLASMA PHYSICS } \\
\text { COMPUTATIONAL } \\
\text { PHYSICS }\end{array}$ & $\begin{array}{l}\text { In parallel: } \\
\text { NUCLEAR PHYSICS } \\
\text { ASTRONOMY- } \\
\text { COMPUTATIONAL } \\
\text { PHYSICS } \\
\text { CONDENSED MATTER- } \\
\text { LOW TEMPERATURE } \\
\text { PHYSICS } \\
\text { QUANTUM } \\
\text { ELECTRONICS }\end{array}$ \\
\hline $\begin{array}{l}20.00 \\
\text { to } \\
22.00\end{array}$ & $\begin{array}{l}\text { Physics and Society - } \\
\text { Public policy and } \\
\text { current prospects } \\
\text { G. Diemer (Eindhoven, } \\
\text { The Netherlands) }\end{array}$ & $\begin{array}{l}\text { Physics and society } \\
\text { A. King (OECD, France) }\end{array}$ & $\begin{array}{l}\text { Origin of biological } \\
\text { information } \\
\text { M. Eigen } \\
\text { (Gottingen, FDR) }\end{array}$ & $\begin{array}{l}\text { The computer and the } \\
\text { teaching of physics } \\
\text { Speaker not confirmed }\end{array}$ \\
\hline
\end{tabular}

\section{ATOMIC PHYSICS}

Bound states and continuum states of atomic systems M.J. Seaton (London)

Spectroscopy with lasers

W. Demtröder (Kaiserslautern, FDR)

Ionic excitation of Inner shells of atoms

B. Fastrup (Aarhus, Denmark)

ATOMIC AND MOLECULAR PHYSICS

Relativistic effects in atomic spectra

S. Feneuille (Orsay, France)

Optical pumping of lons

G. zu Putlitz (Heidelberg, FDR)

Molecular physics

K. Dressler (Zurich, Switzerland)

\section{COMPUTATIONAL PHYSICS}

Computational models in plasma physics M.R. Feix (Nancy, France)

Computer simulation in plasma physics D. Biskamp (Munich, FDR)

COMPUTATIONAL PHYSICS -

ADVISORY COMMITTEE FOR APPLIED PHYSICS AND PHYSICS IN INDUSTRY

Band structure calculations in seml-conductors

J. Treusch (Dortmund, FDR)

Computations on phonon spectra

of superconductor tunnel characteristics

K. Knorr (Frankfurt, FDR)

Computer simulation

of phase transitions in finite systems

$T$. Schneider (Zurich, Switzerland)
Calculation of the structure of electron guns

$S$. Fergusson (Eindhoven, The Netherlands)

Satellite orbit caclulations

H. Göllnitz (Schrobenheusen, FDR)

Particle orbits in cyclotrons

N. Vogt-Nilsen (Geneva, Switzerland)

CONDENSED MATTER -

LOW TEMPERATURE PHYSICS

Neutron diffraction

$T$. Springer (Jülich, FDR)

A15 alloys

J. Labbé (Orsay, France)

Electronic states on surfaces

J.L. Beeby (Harwell, UK)

Superplasticity of metals

D.J. Dingley (Bristol, UK)

Microanalysis by nuclear activation

G. Amsel (Paris)

HIGH ENERGY AND PARTICLE PHYSICS

Physics with colliding lepton beams

A. Zichichi (Bologna, Italy)

New developments in the theory of weak interactions

J. Prentki (Geneva, Switzerland)

Physics with colliding hadrom beams

A. Wetherell (Geneva, Switzerland)

HIGH ENERGY AND PARTICLE PHYSICS NUCLEAR PHYSICS

Asymmetry in mirror Gamow Teller $\beta$-decay D.H. Wilkinson (Oxford, UK)

Title not yet known

T. Ericson (Geneva, Switzerland)
NUCLEAR PHYSICS

Nuclel far from stability

R. Klapisch (Orsay, France)

Fleld of superheavy nuclel

Z. Szymanski (Warsaw)

Nuclear spectra B. Mottelson

(Copenhagen)

PLASMA PHYSICS

Plasma experiments in space

R. Lust (Munich, FDR)

Plasma phenomena in high-energy astrophysics

B. Coppi (Cambridge, USA)

Plasma waves

J.L. Delcroix (Orsay, France)

On the way to a fusion reactor

A. Schlüter (Munich, FDR)

Numerical simulation of plasma phenomena

K.V. Roberts (Abingdon, UK)

\section{QUANTUM ELECTRONICS}

High-power lasers

M. Michon (Marcoussis, France)

Tunable Infra-red light sources

S.D. Smith (Edinburg, UK)

Dye lasers

E.P. Schafer (Göttingen, FDR)

Pico-second phenomena and their measurement

D.J. Bradley (Belfast, UK)

Semi-conductor lasers

M.H. Pilkuhn (Karlsruhe, FDR)

Self-focussing and self-trapping

O. Svelto (Milan, Italy)

Applications of coherent optics

J.-Ch. Viénot (Besançon, France) 